\title{
Juridic review of legal protection for health personnel in radiology in relationship with legal assurance
}

\author{
Ginanjar Giwanatara ${ }^{1}$, Daniel Hendrawan ${ }^{2 *}$ \\ 1, 2 Faculty of Law, Maranatha Christian University, Bandung, Indonesia
}

\section{Keywords \\ Legal protection \\ Health personnel \\ Legal assurance \\ Radiation \\ Health workers}

Received: 07 February 2021

Accepted: 18 April 2021

Published: 28 June 2021

\begin{abstract}
This research aims to highlight the sensitive and critical issue of exposure to radiation by health workers in general and specifically in Indonesia. The high use of radiation for medical personnel is the second largest contributor of radiation sources that we receive, which, in addition to providing benefits, can also cause harm to health workers. Therefore, radiology services must pay attention to radiation safety aspects according to Bapeten Regulation No. 8 of 2011 on the safety of using diagnostic radiological X-rays. The fact that the use of ionizing radiation source equipment is still mostly done by hospitals, whether it's due to the lack of education and the quality of human resources, the human error factor, or the sudden damage to the ionizing radiation device, is unknown. A comprehensive review technique was used to gather and content analyzes of the literature, and by applying the normative juridical method, results revealed a legal gap in the regulatory framework of health services that need to be improved through legislation. This review research suggests key policy and practice insights and future research directions.
\end{abstract}

(C) 2021 The Author(s). Published by TAF Publishing.

\section{INTRODUCTION}

\section{Background of the Research}

Health is a human right and one of the elements of welfare that must be achieved following the ideals of the Indonesian nation as stated in the Pancasila, which is very important for developing Indonesian human resources and improving the nation's health (Awaliah, Oktavien, et al., 2021). Health workers are the main component of providing health services to the community in accordance with national goals as used by the constitution, as the main component of providing health services is very important in health development activities (Fileni et al., 2010; Purwanto \& Purba, 2017). The implementation and utilization of the existence of the roles and responsibilities of these health workers are running well, balanced, orderly, quality-maintained, and well protected for the health workers themselves and for the people who receive the health services. Article 1 point 6 of the Health Law in conjunction with Article 1 number 1 of Law Number 36 of 2014 concerning Health Workers defines health. Workers as people who are dedicated to the health sector and have the knowledge and/or skills through education in the health sector which for some types is the authority to make health efforts (Awaliah et al., 2021).

\section{Significance and Gap in Literature}

There is a paucity of research related to legal exploration of regulatory frameworks about exposure to radiation and its side effects on health workers. Especially such research attempts are scarce in Indonesian legal literature and social science publications. This research aims to bridge this gap by exploring this unique concept using Indonesian legal data content analysis. Legal protection ensures the protection of human rights that others violate, and this protection is given to the community so that they can enjoy all the rights granted by law. In other words, legal protection is a legal effort that law enforcement officials must make to give a sense of safety, both mentally and physically, from disturbances and various threats from anywhere (Subarsyah, 2021). Radiology services are health services that use radioactive rays so that these materials can be useful for diag-

\footnotetext{
${ }^{*}$ corresponding author: Daniel Hendrawan

†email: daniel.hendrawan@rocketmail.com
} 
nosis and therapy of diseases, but on the other hand, they can be very dangerous if their use is not appropriate and not controlled (Awaliah et al., 2021).

The implementation of radiology services has usually been carried out in various health facilities. The development of science and technology has made it possible for various diseases to be detected using radiology facilities, namely ionizing and non-ionizing radiation. With time, diagnostic radiology has also progressed rapidly, both in terms of equipment and methods (Awaliah et al., 2021). To improve the quality of radiology services, especially diagnostic radiology, guidelines for diagnostic radiation installation services are made as a reference for health services in providing radiology services and for coaching purposes.

Radiation is the energy emission through temperature or space in heat, particles, or electromagnetic waves from a radiation source. Judging from the process of formation, radioactive elements or radioactive sources that exist in this environment can be grouped into large groups, namely natural radiation sources and artificial radiation sources. It is said that natural radiation sources also recognize the existence of artificial radiation sources, namely radiation sources that in the process of formation involve human intervention, whether the radiation source is intentionally created for a specific purpose or is a by-product of the use of nuclear technology by humanity. In this case, the radiation source is not intentionally made by humans. The following are radiation sources in the environment, both natural and artificial radiation sources.

Ionizing radiation is applied constructively in various fields such as medicine, research, manufacturing, construction, and many others but presents a health hazard if proper measures against undesired exposure are not followed. Exposure to ionizing radiation causes damage to living tissue and can result in mutations, radiation sickness, cancer, and death (Subarsyah, 2021).

Health services are the main tasks that the government must carry out, both health services and individual health services, to provide comprehensive and sustainable health services; the government established a national health system in 1989 by the Minister of Health. To understand health services, it is necessary to first explain the meaning of health services in a halifah sense, meaning to serve is to provide people's needs. In contrast, the meaning of service is the thing, the way, the result of the work of serving (Subarsyah, 2021). This study context and the idea of exploration of legal landscape related to exposure, safety, and measures related to radiation in hospitals is unique in multiple terms and greatly significant to the body of knowledge.
It may help policymakers and legislators to make amendments to the existing regulatory framework related to this phenomenon.

\section{Research Objectives}

The study aims to achieve the following objectives:

1. Highlight the importance of this risk hazord for health workers and generate awareness.

2. Grab the attention of policymakers, hospital management, and legislators towards this important matter.

3. Grab the attention of health and law scholars towards this significant area of new research, especially in Indonesian and generally in developing countries.

\section{LITERATURE REVIEW}

Health workers are the main component of providing public health services following national goals as utilized by the constitution, as the main component of health service providers, of course, the existence, roles and responsibilities of these health workers are running well, balanced, regular, maintained in quality, and well protected for health workers. Of course, health care needs to be regulated in legislation. Article 1 point 6 of the Health Law in conjunction with Article 1 of Law Number 36 of 2014 concerning health workers, defines health personnel as anyone who devotes himself to the health sector and has knowledge and skills through education in the health sector, which for certain types is the power to perform health services (Passat \& Israhadi, 2021).

Ionizing radiation is applied constructively in various fields such as medicine, research, manufacturing, construction, and many others but presents a health hazard if proper measures against undesired exposure are not followed. Exposure to ionizing radiation causes damage to living tissue and can result in mutations, radiation sickness, cancer, and death (As \& Purba, 2017; Sutarno \& Maryati, 2021).

According to Article 58 of Law 36 of 20114, the obligations and rights of health workers are to provide health services and professional ethics as well as the health needs of health service recipients. Obtaining approval from recipients of health services for the actions given, maintaining the confidentiality of the health of recipients of health services, care and actions taken, referring recipients of health services to other health workers who have the appropriate competence and authority. Article 59 explains that health workers who practice at health service facilities are obliged to provide first aid to patients in an emergency or disaster situation to save lives and prevent disability (Nurul Hidayati, 2021; Niha, Jantarasiriput, Tonyongdalaw, \& Vaichompu, 
2016). The right of health workers to complete and correct information from health service recipients, obtain protection for occupational safety and health and treat human dignity following human dignity.

Legal certainty is a system of norms; norms are statements that emphasize the "should" aspect by stating some rules about what should be done. Norms are the product of deliberative human action. Laws that contain general rules serve as guidelines for individuals to behave in society, both concerning fellow individuals and in relations with the community. These rules become limitations for society in burdening or taking actions against individuals. The existence of these rules and the implementation of these rules give rise to legal certainty (Sutarno \& Maryati, 2021; Olkinuora \& Lrappänen, 1987).

Legal goals that are close to reality are legal certainty and legal benefits. Positivism puts more emphasis on legal certainty, while the functionalists prioritize the usefulness of the law, and it can be argued that "summum ius, summa injuria, summa lex, summa crux" which means that harsh laws can hurt unless justice can help them, even though justice is not the sole purpose of the law, but the most substantive goal of the law is justice (Nurul Hidayati, 2021; Pitarti \& Subekti, 2019).

\section{RESEARCH METHOD}

The method used in this study is a normative juridical method that emphasizes legal norms by analyzing the relevant laws and regulations. In this study, the researcher used two approaches: first, to examine all laws and regulations related to the problems (legal issues) being faced. Second, the approach of the views and doctrines that developed in the science of law (Passat \& Israhadi, 2021).

The nature of descriptive legal research is legal research that is descriptive in nature. This research aims to obtain a complete picture of positive law, including related legal events (Passat \& Israhadi, 2021). A thorough literature review of historical data, books, magazines, and articles was performed to gather the relevant information. In the second phase, a deep content analysis was performed to shortlist the most related information to the topic of the study and was used for further analysis.

\section{ANALYSIS AND DISCUSSION Legal Protection for Health Workers in the Field of Di- agnostic Radiology}

Legal protection for health workers in radiology is legal protection regarding certain things to get a safe place or regulate something by law so that rights and obligations are protected by law. Consequently, any act performed under the applicable legal provisions will benefit from legal protection. Protecting each other's interests, then humans in society must remember, take into account, maintain, and respect the interests of other humans, lest some conflicts and conflicts harm others (Passat \& Israhadi, 2021).

If a health worker is harmed by an act of another, whether malicious or negligent, the health worker can claim legal, civil, criminal, or administrative liability from those subjects. In addition to the existence of compensation, legal assistance, and repayment of good reputation are inferred from health professionals' rights and duties (Passat \& Israhadi, 2021).

Responsibilities and duties of health service facilities in radiology are very important, aiming to be a reference developing knowledge and expertise to improve the professionalism of radiographers. This includes general competencies, namely competencies that must be possessed and mastered in the context of globalization, and specific competencies, namely competencies related to the duties and functions of radiology.

Legal responsibilities in civil terms are responsibility and liability; responsibility means things that can be explained by an obligation and includes decisions, skills, capacities, and competencies, including the obligation to be responsible for the applied laws. In the sense and use of the practice, the term responsibility refers to political responsibility or responsibility for one's faults. Liability is a broad legal term denoting almost any character of risk or liability, which is certain, which depends on covering all the characteristics of real rights and obligations such as losses, threats, crimes, costs, or other people (Guerra, 2021).

In principle, hospitals are civilly responsible for all activities carried out by health workers following article 1367 (3) of the Civil Code. In addition, the hospital is also responsible for default and acts against the law $(1243,1370,1371,1365$ of the Civil Code). The role and function of the hospital as a place to provide professional health services is closely related to the quality elements that are guaranteed quality, profits, or benefits reflected in the quality of service and, finally, the law that regulates hospitals in general (Subarsyah, 2021).

The hospital's responsibility when there is malpractice Law No. 44 of 2009 concerning hospitals regulates all matters relating to hospitals, including human resources. Article 46 states the legal responsibility of hospitals, namely hospitals are legally responsible for all losses caused by negligence committed by health workers. This article can also reduce the sense of responsibility of health workers in handling 
patients because the hospital takes legal responsibility for their mistakes. The hospital is not an individual who can be punished so that those affected by this negligence are the owners and management of the hospital. Legal protection is not a provision that eliminates the possibility of legal prosecution by other people but provides health workers following statutory provisions to work in accordance with the profession without coercion and threats by other parties. Get the opportunity to defend themselves and be processed fairly if they are suspected of having committed a professional violation, both in hospital institutions and in general courts (King, 1978).

\section{Implications for Policy Directions}

Provisions for radiation safety equipment permit holders are responsible for realizing radiation safety objectives, compiling, developing, implementing, and documenting radiation protection and safety programs. Which is made based on the nature and risks for each implementation of the use of nuclear energy, establish and determine radiation safety managers in facilities or agencies in accordance with their duties and responsibilities, determine the actions and resources needed to achieve the objectives, and ensure that these resources are adequate and can be taken properly.

The regulation of the supervision of the safety of health workers is carried out so that the radiation dose received by health workers involved in the implementation of radiation safety must comply with the concept of radiation protection in the use of nuclear power for both humans and the environment, which includes the effect of radiation on health through the large dose received and understands the principle of protection in limiting dose recipients.

Provisions for safety and security of ionizing radiation equipment in the field of radiology, the head of the hospital, the head of the radiology room, who is in charge of radiation safety, permits the holder to provide personnel as stipulated in BAPETEN regulation no. 8 of 2011 Article 11b, according to the type of ionizing beam used and the purpose of use (Herawati, Herwastoeti, \& Isrok, 2021).

The safety of radiation workers must be in accordance with existing SOPs and try not to repeat the x-rays to avoid overexposure. According to BAPETEN, every radiation worker who carries out radiological examinations must prevent repeated exposures (Nurul Hidayati, 2021).

\section{CONCLUSION}

What is the legal protection of health professionals in the radiological field in terms of legal certainty? With the existence of law no. health. Hospital managers must guarantee the health and safety of hospital human resources, patients, and caregivers; therefore, hospital managers must carry out occupational health and safety activities in an integrated, comprehensive manner and sustainable so that the risk of occupational accidents and infectious diseases. Hospitalization can be avoided. Article 57 letter (a) states that health professionals have the right to legal protection as long as they perform their duties in accordance with operational standards, letter (d) obtains protection for occupational safety and health, treatment consistent with human dignity, morality, decency, and religious values. It is a very important obligation that hospitals apply in the workplace for occupational safety and health. In its implementation, occupational safety aims to protect workers' rights to safety in the performance of work for the well-being of life and to increase national production and productivity, ensure the safety of all others in the workplace, and maintain and use productive resources safely and efficiently. One of the ways that hospitals can protect healthcare workers is to make an early diagnosis with periodic medical examinations. One of the factors that cause workplace accidents is ionizing radiation, which is too dangerous for the human body to perceive radiation. Raises the concern of workers whether or not they are exposed to radiation. The use of radioactive materials must be carried out correctly to avoid the risk of radiation.

\section{Limitations \& Future Research Directions}

This research has limited enough data to generalize the findings towards the majority population due to the unique nature and area of the research concept. So future researchers may adopt a comprehensive methodological approach through which, along with secondary data, the primary data from all stakeholders may also be incorporated to give a 360-degree view of the conceptualization. Future researchers may Also look for comparative analysis on safety legislations between ASEAN countries related to radiology exposure, its measures by hospital management and governmental bodies. Such comparative analysis may bring key policy directions for policymakers and future researchers.

\section{REFERENCES}

As, Y., \& Purba, C. S. (2017). The urgency of pontianak local public policy in emboding legal protection against teacher. International Journal of Humanities, Arts and Social Sciences, 3(6), 241-248. doi:https://doi.org/10.20469/ijhss.3 .20001-6 
Awaliah, N., Oktavien, S., et al. (2021). Legal review of action physicians that do not give patients diagnosis results to patients (case study of medan high court's decision no. 33/pdt/2015/pt-mdn). Review of International Geographical Education Online, 11(6), 1451-1458. doi:https://doi.org/10.48047/rigeo.11.06.159

Fileni, A., Magnavita, N., Mirk, P., Iavicoli, I., Magnavita, G., \& Bergamaschi, A. (2010). Radiologic malpractice litigation risk in Italy: An observational study over a 14-year period. American Journal of Roentgenology, 194(4), 1040-1046. doi:https://doi.org/10.2214/AJR.09.3457

Guerra, G. (2021). Evolving artificial intelligence and robotics in medicine, evolving european law comparative remarks based on the surgery litigation (Just accepted). Maastricht Journal of European and Comparative Law. doi:https:// doi.org/10.1177/1023263X211042470

Herawati, T., Herwastoeti, H., \& Isrok, M. (2021). Online health consultation services in Indonesia law perspective. In International Conference on Indonesian Legal Studies, Semarang, Indonesia . doi:https://eudl.eu/doi/10.4108/eai.1-7 $-2020.2303667$

King, P. A. (1978). The juridical status of the fetus: A proposal for legal protection of the unborn. Michigan Law Review, 77, 1647-1687. doi:https://doi.org/10.2307/1288038

Niha, S., Jantarasiriput, B., Tonyongdalaw, N., \& Vaichompu, N. (2016). Reproductive health among Bangoebadae muslim women: Cervical cancer care. International Journal of Health and Medical Sciences, 2(3), 52-57. doi:https://doi.org/ 10.20469/ijhms.2.30002-3

Nurul Hidayati, P. (2021). Institutional form of the policy guarantee program in Indonesia (comparative study between Indonesia and Malaysia and South Korea). Dharmasisya, 1(3), 1383-1394.

Olkinuora, M. A., \& Lrappänen, R. A. (1987). Psychological stress experienced by health care personnel. Scandinavian Journal of Work, Environment \& Health, 13(1), 1-8.

Passat, S. A., \& Israhadi, E. I. (2021). Confidentiality of medical record as legal protection of patient's privacy rights. In Proceedings of the 1st International Conference on Law, Social Science, Economics, and Education, Salatiga, Indonesia. doi:https://doi.org/10.4108/eai.6-3-2021.2306395

Pitarti, I., \& Subekti, R. (2019). Legal protection of medical records of covid-19 patients in Indonesia and legal measures of spread prevention. International Journal of Advanced Science and Technology, 29(5), 1068-1074.

Purwanto, \& Purba, C. S. (2017). Legal aid compliance for poor local community. Journal of Advanced Research in Social Sciences and Humanities, 2(6), 363-370. doi:https://doi.org/10.26500/jarssh-02-2017-0604

Subarsyah, T. (2021). Political crime paradigm in legal perspective in Indonesia (philosophical juridical studies in the viewpoint of michel foucalt). Journal of Legal, Ethical and Regulatory Issues, 24(1), 1-11.

Sutarno, S., \& Maryati, M. (2021). Information of medical malpractice and risks in the informed consent process before surgery in Indonesia. Yustisia Jurnal Hukum, 10(2), 269-290. doi:https://doi.org/10.20961/yustisia.v10i2.52132 